\title{
The importance of the early diagnosis of aorta coarctation
}

\author{
Luana Resende Cangussú \\ ID Matheus Rodriques Lopes ${ }^{2}$ \\ (iD) Romero Henrique de Almeida Barbosa²
}

1. Medical student, Federal University of Vale do São Francisco, Paulo Afonso, Bahia, Brasil. 2. Professor, Federal University of Vale do São Francisco, Paulo Afonso, Bahia, Brasil.

\section{SUMMARY}

INTRODUCTION: Coarctation of the aorta is a congenital heart disease characterized by a narrowing that occurs in the aortic artery. This constriction can occur anywhere along its entire length; however, it is more common between the origin of the left subclavian artery and the ductus arteriosus. Its incidence corresponds to 3 cases per 10,000 births. Thus, it is a common cardiopathy, but with high mortality and morbidity rates, which are related to a failure in the early diagnosis.

METHOD: In the research, articles of the national and international literature in Pubmed, Scielo and Lilacs databases were selected using the following descriptors: coarctation, aorta, diagnosis, heart diseases, congenital abnormalities.

RESULTS: The pathophysiology of COA and its systemic implications in the life of newborn and adults are well elucidated. However, due to the lack of habit to palpate pulses and to check the blood pressure in both upper and lower limbs during the physical examination, it is still a pathology little diagnosed in childhood. There are several techniques used in the repair of coarctation, each with their specifics, although, when not treated, aneurysms, heart failure, coronary diseases, and stroke are the main complications arising from the evolution of this pathology, which explains the low survival rate of these patients.

CONCLUSION: Coarctation of the aorta is, therefore, a cardiac malformation of significant importance due to its incidence and its significant mortality risk. In this sense, the early diagnosis stands out as an essential piece for better prognosis of the patient.

KEYWORDS: Aortic coarctation. Heart defects, congenital. Diagnosis.

\section{INTRODUCTION}

It is estimated that approximately $60 \%$ to $80 \%$ of newborns with aortic coarctation are not diagnosed before hospital discharge. ${ }^{1}$ Thus, it is essential to understand the physiopathology of aortic coarctation and its systemic implications on the life of the newborn and the adult to contribute to the early diagnosis of these patients.

Aortic coarctation is a congenital heart disease characterized by a narrowing of the aorta. This constriction can occur in any location along its entire length; however, it is more common between the origin of the left subclavian artery and the ductus arteriosus. $^{2,3}$

It has an incidence of 5-10\% among all congenital heart diseases and is predominant in males, at a ratio of $2: 1 .^{4-8}$ It is classified as the fifth most common con- 
genital heart disease. ${ }^{9}$ Its incidence in comparison with the number of births corresponds to three cases per 10,000 births. ${ }^{10}$ It is a common heart disease, but it has high mortality and morbidity rates, which are associated with failure to diagnose. ${ }^{11}$

Aortic coarctation can be divided into two distinct groups: critical aortic coarctation and asymptomatic aortic coarctation. In the critical coarctation, severe symptoms are observed over the first two months of life and when left untreated can lead to death. Whereas in the asymptomatic coarctation the main characteristic is the late onset of hypertension on upper limbs. ${ }^{12}$

Aneurysms, heart failure, heart diseases, and cerebrovascular accidents are complications the stem from the evolution of the pathology when left untreated, and such manifestations are direct consequences of secondary hypertension. ${ }^{2}$

Aortic coarctation can be classified as simple or complex. The complex form is associated with the presence of heart anomalies. In the simple form, such anomalies are absent. Heart anomalies usually associated with aortic coarctation are: interventricular communication, bicuspid aortic valve, subvalvular aortic stenosis, and alterations in the mitral valve. ${ }^{13,14}$

The most usual symptoms in patients are: arterial hypertension in the upper limb, reduction of pulses in lower limbs, headache, epistaxis, claudication in the legs and cyanosis. ${ }^{4}$ Coarctation appears as a consequence of the increase in the arterial pressure of the upper limbs and head. ${ }^{15}$ This increased flow can mean a higher risk of saccular aneurysms, increased frequency of headaches, and the development of heart diseases and heart failure ${ }^{16}$ (Figure 2).

This work aims to review the literature on the physiopathology of aortic coarctation and the systemic implications of the condition in the life of the newborns and adults to contribute to the early diagnosis of patients, since this pathology is still underdiagnosed in childhood, since it is not customary to measure the pulse and blood pressure in the upper and lower limbs during a physical examination.

\section{METHODS}

This is a narrative literature review of the literature. Searches were carried out in the PubMed, SciELO, and Lilacs databases. During the search, we selected articles of narrative and systematic reviews, original articles, clinical trials and case reports from
2009 to 2018, in national and international literature, using the following keywords: coarctation, aorta, diagnosis, heart disease, congenital abnormalities.

\section{DISCUSSION}

\section{Pathophysiological aspects}

Aortic coarctation is considered a flow-obstruction pathology. One of its consequences is the increased pressure in the left ventricular chamber, which is overloaded since it needs to pump against the resistance caused by the obstruction of the aorta. ${ }^{17}$

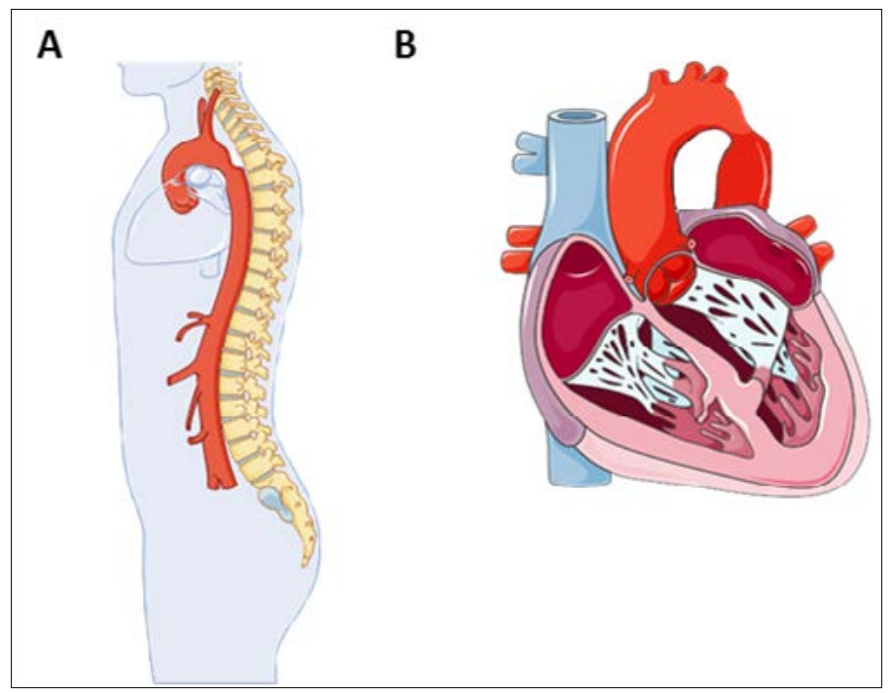

FIGURE 1. Representation of coarctation of the aorta. A) Profile representation of aortic narrowing. Coarctation of the aorta is evidenced by the black arrow. B) Representation in the frontal section of the heart and large vessels; the figure shows the narrowing of the aorta after the origin of the left subclavian artery (evidenced by the black arrow).

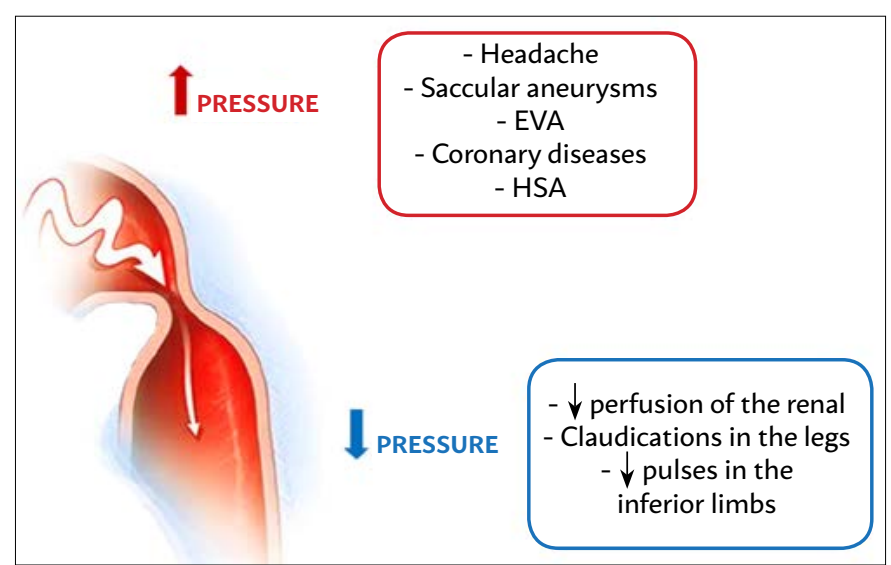

FIGURE 2. Systemic consequences of aortic coarctation. With the increase in pressure (before coarctation), the most common consequences are headache, sacral aneurysms, stroke, coronary heart disease, and systemic arterial hypertension. With the decrease in pressure (after coarctation), there is a decrease in renal perfusion, leg claudication and in the pulses of lower extremities. 
From an embryo point of view, coarctation is still not well understood. However, some theories suggest that there is a disorderly migration of smooth muscle cells from the ductus arteriosus to the wall of the aorta artery; others suggest that there is a change of blood flow in the fetal circulation, with a decrease in the amount of blood that exits the left ventricle to the aorta. ${ }^{13}$

\section{Diagnosis}

In clinical practice, it is observed that many patients are undiagnosed due to the lack of a detailed clinical examination, since measuring the pulse of upper and lower limbs is not routine. ${ }^{4}$ It is estimated that approximately $60 \%$ to $80 \%$ of newborns with aortic coarctation are not diagnosed before hospital discharge. However, this is a pathology that can be easily recognized in clinical practice. ${ }^{1}$

The signs and symptoms vary according to the type of clinical manifestation. The most frequent are hypertension, heart murmurs, headache, epistaxis, and fatigue in the legs. ${ }^{18} \mathrm{~A}$ general and thorough physical examination with the measurement of arterial pressure can reveal a discrepancy in limb arterial blood pressures (differential SBP popliteal/brachial greater than or equal to $20 \mathrm{mmHg}$ ). There is, in these cases, arterial hypertension in the upper limbs, which is related to the obstruction of the coarcted area and the activation of the renin-angiotensin system in response to the decrease in the perfusion of the renal artery below the obstruction. Measuring peripheral pulses (femoral, popliteal, posterior tibial and dorsalis pedis) can reveal weak or missing pulses in the limbs. ${ }^{18}$ During cardiovascular auscultation, systolic murmurs can be noticed on the precordium and, in collateral circulation, heart murmurs in axillary and scapular regions. ${ }^{19.20}$

Aortic coarctation presents a varied clinical spectrum depending on the age of the patient. It can manifest as heart failure in newborns after the closure of the ductus arteriosus, or in asymptomatic forms in adolescents and adults. ${ }^{7.21}$ During the neonatal period, symptomatic newborns have a higher risk of mortality due to congestive heart failure, metabolic acidosis, and shock; on the other hand, asymptomatic children or adults develop complications at a later stage of life, especially related to systemic arterial hypertension. ${ }^{22.23}$

Clinical manifestations depend not only on the severity and location of the coarctation but also on the existence or not of associated anomalies. ${ }^{4}$
Some complementary examinations, such as $\mathrm{x}$-ray, electrocardiogram, transthoracic and transesophageal echocardiography, angiography, computed tomography, and magnetic resonance imaging may assist in the diagnosis. ${ }^{24}$ Prenatal diagnosis using echocardiography has been used and proved to reduce mortality rates and improve survival; nevertheless, it is still challenging to establish a definitive diagnosis using this method. ${ }^{1}$ However, if a prenatal ultrasound suggests the presence of coarctation, the mother can be forwarded to a hospital unit that has a pediatric heart surgery center so that post-natal follow-up can be conducted. ${ }^{22.25}$

In chest X-rays, it is possible to see notches bilaterally in the costal margin, resulting from the erosion of the ribs caused by collateral circulation. This happens because there is an increase in pressure before the coarcted area, so the anterior intercostal arteries present high pressure as well. However, the posterior intercostal arteries, which stem from branches of the thoracic aorta, have lower pressure, so they need to dilate in order to accommodate the high pressure coming from the anterior arteries, due to the anastomosis. The increase in pressure causes the arteries to dilate, and they eventually start to brush against the ribs, forming the notches. In newborns' X-rays, it is possible to notice an increase in the cardiac area and pulmonary congestion. . $^{19,26,27}$

The electrocardiogram can show normal results or hypertrophy of the left ventricle; neonates, it can show a deviation of the cardiac axis to the right and overload of the right ventricular. ${ }^{16}$

The transthoracic echocardiography is the first clinical routine examination to be conducted when there is a suspected case of aortic coarctation since it is a simple exam that provides hemodynamic variables. Although it does not always offer a direct view of the coarcted area, it is important to rule out other cardiac defects, such as bicuspid aortic valve and interventricular communication. During the exam, it is also possible to observe the turbulence of the blood flow from the aorta before the coarcted area and the pressure gradient caused by the coarctation. The transesophageal echocardiography, although invasive, can also be used in the diagnosis of this pathology. ${ }^{13.28}$

Angiography used to be the most widely used method for diagnosing aortic coarctation. However, nowadays it is more indicated for therapeutic intervention or in cases which there is need of additional hemodynamic data. ${ }^{10}$ 
A computed tomography (CT) allows the doctor to identify with high resolution both intracardiac and extracardiac structures, with the possibility of reconstructing the vessel anatomy in $2 \mathrm{D}$ and $3 \mathrm{D}$. The examination has as a disadvantage of using ionizing radiation, especially in pediatric patients. ${ }^{19}$

Cardiac magnetic resonance is currently the gold standard test for evaluating aortic coarctation, and it can be used diagnosing and monitoring the patholo$\mathrm{gy}^{29}$ With this imaging method it is possible to carry out an anatomical and functional assessment of the congenital cardiopathy. ${ }^{30}$

Magnetic resonance imaging allows identifying a more specific location of the aortic coarctation, which is important for a subsequent surgical approach. Besides, it is a method that generates multiplane images, which allow for better viewing. This imaging technique is essential for the pre-operative evaluation of all patients submitted to percutaneous and surgical interventions. ${ }^{27}$ With it, it is possible to also observe other anatomical findings, such as the presence of collateral circulation and abnormalities in heart valves. The advantage of this examination over CT is the non-use of ionizing radiation..$^{28}$

\section{Treatment}

Without intervention, the survival of patients with aortic coarctation is approximately 35 years, with a mortality rate of $75 \%$ at 46 years of age. ${ }^{31.32}$ The reasons that lead to death are diverse and include: cerebrovascular accident, congestive heart failure, rupture of the aorta and bacterial endocarditis. ${ }^{10}$

In 1945, the first successful surgical intervention was described by Crafoord and Nylin. However, during these initial techniques, the recoarctation rates were over $50 \%$, so these strategies were not a permanent solution. Currently, there are several techniques for correcting heart defects, ranging from surgical interventions to the use of a transcatheter. ${ }^{21.33}$ Clinical therapy is based on the initial control of blood pressure, mainly through the use of ACE inhibitors, ARB (angiotensin receptor blocker) and beta-blockers. ${ }^{34}$

Systemic arterial hypertension in children and adults, with a difference in the differential systolic arterial pressure (upper limb/lower limb) greater than $20 \mathrm{mmHg}$ is the most widely accepted indication for intervention. ${ }^{20}$ Other criteria to perform the intervention are: evidence of significant aortic coarctation and collateral circulation in imaging examinations. ${ }^{13.34}$
There are several techniques used to repair the coarctation: resection of the coarcted area with termino-terminal anastomosis, dilatation with a balloon catheter, a flap of the subclavian artery, intravascular stents, catheterization, and aortoplasty with prosthetic graft are some of them..$^{35.36}$

When surgical repair is used, it can be accomplished technically by resecting the coarcted segment, which is usually the treatment of choice in neonates and infants. In adults, resection with interposition grafting is also an option. ${ }^{9}$ In the elderly, calcifications and atherosclerosis may hinder surgical repair. ${ }^{37}$ The success rate of the procedure is high, with surgical mortality rates lower than $1 \%{ }^{9}$

Balloon angioplasty can be a palliative option before the definitive correction. Its goal is to stabilize high-risk patients that cannot be submitted to immediate surgical intervention, such as, for example, premature newborns. ${ }^{13}$ Moreover, it is an alternative when there are no stents available. ${ }^{38}$

The use of endovascular stents is currently an innovation in the treatment of aortic coarctation. These devices provide structural support to the artery and decrease the rates of vascular trauma in the aorta and aneurysms when compared to balloon angioplasty. The use of stents has contributed mainly in cases of complex coarctation anatomy and in the elderly since they often present arteriosclerosis and calcifications. Currently, with technological advances, efforts are being made to achieve the characteristics of an ideal stent, with a higher potential of dilation, greater flexibility, and lower profile. The four most used types worldwide are Palmaz "10", Genesis XD, Ev3 Maxi and CP. ${ }^{7.10}$ These are currently the first option for children (weight $>25 \mathrm{~kg}$ ) and adults. This procedure has the advantage of being less invasive..$^{13,34,36}$

Some guidelines recommend that the repair is done as early as possible, as in early childhood, to increase the life expectancy of the patient and reduce long-term morbidity. ${ }^{35.39}$ It is important to emphasize that, irrespective of the interventional technique used, it can result in complications in the long term, the main ones being hypertension, aortic aneurysm, and recoarctation. In $10 \%$ of patients undergoing a surgical intervention to correct aortic coarctation, hypertension remains or relapses; however, the earlier the correction, the higher the chances of the individual maintaining a healthy blood pressure behavior. It is estimated that recoarctation can occur regardless of the technique used, with rates ranging from $5 \%$ to $14 \%$, 
but it tends to be more common in neonates. ${ }^{36,40,41}$

The ideal treatment for correcting aortic coarctation remains under debate due to the lack of long-term clinical and imaging data to compare the different techniques used for correction. ${ }^{7.42}$ Thus, it is noteworthy that the adequate technique should be selected by a multidisciplinary team, taking into consideration the specificities of each patient, such as age, comorbidities and other associated cardiac lesions. ${ }^{41}$

After choosing and performing the appropriate treatment, it is necessary to have a permanent follow-up of the patient with the cardiology team, with regular examinations such as electrocardiogram, echocardiogram and treadmill stress tests, in order to monitor and assess cardiac function, as well have an early detection of changes, so as to intervene with a specific treatment. It is also always necessary to monitor the blood pressure since systemic hypertension is the major risk factor for the onset of other pathologies. ${ }^{38.40}$

\section{CONCLUSION}

Aortic coarctation is a common congenital cardiopathy that has high morbidity and mortality rates and is usually associated with failure in diagnosis. This pathology can be divided into two distinct groups: critical aortic coarctation and asymptomatic aortic coarctation. Aneurysms, heart failure, heart diseases, and cerebrovascular accidents are complications the stem from the evolution of the pathology when left untreated, and such manifestations are direct consequences of secondary hypertension. ${ }^{14}$

\section{Acknowledgments}

We thank Dyowani dos Santos Basílio for formatting the figures in the article.

\section{Ethical aspects:}

The authors declare there are no conflicts of interest.

\section{RESUMO}

INTRODUÇÃO: A coarctação da aorta é uma cardiopatia congênita caracterizada por um estreitamento que ocorre na artéria aorta. Essa constrição pode ocorrer em qualquer local ao longo de toda a sua extensão, entretanto, é mais comum entre a origem da artéria subclávia esquerda e o ducto arterioso. Sua incidência corresponde a três casos a cada 10.000 nascimentos, sendo, desse modo, uma cardiopatia comum, porém com elevada taxa de mortalidade e morbidade, as quais estão relacionadas à falha no diagnóstico precoce.

MÉTODOS: Este artigo trata-se de uma revisão bibliográfica narrativa da literatura. Na pesquisa foram selecionados artigos na literatura nacional e internacional nas bases de dados PubMed, SciELO e Lilacs, utilizando-se os seguintes descritores: coarctação, aorta, diagnóstico, cardiopatias, anormalidades congênitas.

RESULTADOS: A fisiopatologia da coarctação da aorta e as implicações sistêmicas dessa cardiopatia na vida do recém-nascido e do adulto estão bem elucidadas. Entretanto, devido à falta de costume em palpar pulsos e aferir a pressão arterial nos membros superiores e inferiores durante o exame físico, ainda é uma patologia pouco diagnosticada na infância. Existem diversas técnicas utilizadas no reparo da coarctação, cada uma com suas especificidades, porém, quando não tratada, aneurismas, insuficiência cardíaca, coronariopatias e acidentes vasculares encefálicos são as principais complicações provenientes da evolução dessa patologia, o que explica uma baixa sobrevida desses pacientes.

CONCLUSÃO: A coarctação da aorta é, portanto, uma malformação cardíaca de importância relevante devido a sua incidência e ao seu potencial risco de mortalidade. Nesse sentido, o diagnóstico precoce destaca-se como peça fundamental para um melhor prognóstico do paciente.

PALAVRAS-CHAVE: Coartação aórtica. Cardiopatias congênitas. Diagnóstico.

\section{REFERENCES}

1. Evers PD, Ranade D, Lewin M, Arya B. Diagnostic approach in fetal coarctation of the aorta: a cost-utility analysis. J Am Soc Echocardiogr. 2017;30(6):589-94.

2. Santos MA, Azevedo VM. Aortic coarctation. Congenital anomalies with new perspective in the treatment. Arq Bras Cardiol. 2003;80(3):340-6.

3. Longo DL, Kasper DL, Jameson JL, Fauci AS, Hauser SL, Loscalzo J. Medicina interna de Harrison. 18a ed. Rio de Janeiro: McGraw Hill; 2013.

4. Silva D, laneiro-Acabado A, Nogueira |B. Coarctação da aorta em adultos: revisão. Rev Portuguesa de Hipertensão e Risco Cardiovascular. 2010;18:10-3.

5. Carvalho ATY, Silva GSA, Pereira MCSB, Santos AJ, Majdalan VC, Santos VP, et al. Tratamento endovascular da coarctação da aorta: relato de caso. | Vasc Bras. 2012;11(1):57-61.
6. Sociedade de Cardiologia do Estado de São Paulo. Coarctação da aorta 2015. In: Cardiopatias Congênitas, um novo olhar: diagnóstico e tratamento [Internet]. São Paulo SOCESP. [cited 2018 Apr 15]. Available from: http:// www.socesp.org.br/upload/revista/2015/REVISTA-SOCESP-V25-N3. pdf

7. Peres A, Martins JDF, Paramés F, Gil R, Matias C, Franco J, et al. Coarctação isolada da aorta: experiência em 100 doentes consecutivos. Rev Port Cardiol. 2010;29(1):23-35.

8. Bugeja I, Cutajar D, Zahra C, Parascandalo R, Grech V, DeGiovanni JV. Aortic stenting for neonatal coarctation of the aorta: when should this be considered? Images Paediatr Cardiol. 2016;18(3):1-4.

9. Kenny D, Hijazi ZM. Coarctation of the aorta: from fetal life to adulthood Cardiol J. 2011;18(5):487-95. 
10. Torok RD, Campbell MJ, Fleming GA, Hill KD. Coarctation of the aorta: Management from infancy to adulthood. World J Cardiol. 2015;7(11):76575.

11. Al Balushi A, Zacharias $S$, Al Senaidi K. Coarctation of the aorta, known yet can be missed. Oman Med J. 2013;28(3):204-6.

12. Hoffman JI. The challenge in diagnosing coarctation of the aorta. Cardiovasc J Afr. 2018;29(4):252-5.

13. Dijkema EJ, Leiner T, Grotenhuis HB. Diagnosis, imaging and clinical management of aortic coarctation. Heart. 2017;103(15):1148-55.

14. Jurcut R, Daraban AM, Lorber A, Deleanu D, Amzulescu MS, Zara C, et al. Coarctation of the aorta in adults: what is the best treatment? Case report and literature review. J Med Life. 2011;4(2):189-95.

15. Mesquita SMF, Lopes AAB. Hipertensão arterial por coarctação de aorta em adultos. Rev Bras Hipertens. 2002;9(2):192-8.

16. Bonow RO, Mann DL, Zipes DP, Libby P. Braunwald tratado de doenças cardiovasculares. 9a ed. Amsterdam: Elsevier; 2013. 2200p.

17. Jashari $H$, Rydberg A, Ibrahimi P, Bajraktari $G$, Henein MY. Left ventricular response to pressure afterload in children: aortic stenosis and coarctation: a systematic review of the current evidence. Int | Cardiol. 2015;178:203-9.

18. Luz DABPC, Bernardi FLM, Staszko K, Colombo FMC, Bortolotto LA Coarctação aórtica atípica como etiologia de hipertensão arterial e insuficiência cardíaca grave em mulher de 55 anos. Rev Bras Hipertens. 2011;18(2):67-70

19. Boris JR. Primary-care management of patients with coarctation of the aorta. Cardiol Young. 2016;26(8):1537-42.

20. Erbel R, Aboyans V, Boileau C, Bossone E, Bartolomeo RD, Eggebrecht $H$, et al; ESC Committee for Practice Guidelines. 2014 ESC Guidelines on the diagnosis and treatment of aortic diseases: Document covering acute and chronic aortic diseases of the thoracic and abdominal aorta of the adult. The Task Force for the Diagnosis and Treatment of Aortic Diseases of the European Society of Cardiology (ESC). Eur Heart J. 2014;35(41):2873-926.

21. Rubira C). Colocação de endoprótese vascular versus cirurgia para coarctação de aorta: revisão sistemática [Tese de doutorado]. Botucatu: Universidade Estadual Paulista Julio de Mesquita Filho. Faculdade de Medicina de Botucatu; 2012

22. Patel D, Patel S, Sheth M, Rana Y, Sanghvi M, Joshi Y. A rare case of severe aortic coarctation amounting to functional interruption. Gujarat Medical Journal. 2014;69(2).

23. Huang F, Chen Q, Huang WH, Wu H, Li WC, Lai QQ. Diagnosis of congenital coarctation of the aorta and accompany malformations in infants by multi-detector computed tomography angiography and transthoracic echocardiography: a Chinese clinical study. Med Sci Monit. 2017;23:230814.

24. Croti UA, Braile DM, Espada DP, Villegas BM. Correção de coarctação de aorta com interposição de tubo em criança de 12 anos. Rev Bras Cir Cardiovasc. 2010;25(4):596-7.

25. Buyens A, Gyselaers W, Coumans A, Al Nasiry S, Willekes C, Boshoff D et al. Difficult prenatal diagnosis: fetal coarctation. Facts Views Vis Obgyn. 2012;4(4):230-6

26. Carneiro C, Saraiva |, Santos B. Caso clínico ARP no 7: Coarctação da artéria aorta. Acta Radiol Port. 2016;XXVIII(108):53-5.
27. Usman MH, Rengifo-Moreno P, Janzer SF, Inglessis-Azuaje I, Witzke-Sanz C. Coarctation of the aorta: management, indications for intervention, and advances in care. Curr Treat Options Cardiovasc Med. 2014;16(10):341.

28. Thakkar AN, Chinnadurai $P$, Lin $\mathrm{CH}$. Imaging adult patients with coarctation of the aorta. Curr Opin Cardiol. 2017;32(5):503-12.

29. Karaosmanoglu $A D$, Khawaja RD, Onur MR, Kalra MK. CT and MRI of aortic coarctation: pre- and postsurgical findings. AJR Am J Roentgenol. 2015;204(3):W224-33.

30. Fratz S, Chung T, Greil GF, Samyn MM, Taylor AM, Valsangiacomo Buechel ER, et al. Guidelines and protocols for cardiovascular magnetic resonance in children and adults with congenital heart disease: SCMR expert consensus group on congenital heart disease. J Cardiovasc Magn Reson. 2013;15:51.

31. Forbes T), Gowda ST. Intravascular stent therapy for coarctation of the aorta. Methodist Debakey Cardiovasc J. 2014;10(2):82-7.

32. Ferreira EC, Nina VIS, Assef MAS, Silva NAC, Gaspar SFD, Silva FACC, et al. Correção cirúrgica da coarctação da aorta em adultos sob assistência circulatória extracorpórea esquerda. Rev Bras Cir Cardiovasc. 2012;27(1):97102.

33. Zussman ME, Hirsch R, Herbert C, Stapleton GE. Transcatheter intervention for coarctation of the aorta. Cardiol Young. 2016;26(8):1563-7.

34. Warnes CA, Williams RG, Bashore TM, Child IS, Connolly HM, Dearani JA, et al. ACC/AHA 2008 guidelines for the management of adults with congenital heart disease: a report of the American College of Cardiology/ American Heart Association Task Force on Practice Guidelines (Writing Committee to Develop Guidelines on the Management of Adults with Congenital Heart Disease). Developed in collaboration with the American Society of Echocardiography, Heart Rhythm Society, International Society for Adult Congenital Heart Disease, Society for Cardiovascular Angiography and Interventions, and Society of Thoracic Surgeons. I Am Coll Cardiol. 2008;52(23):e143-e263.

35. Tinoco ECA, Botelho AC, Luquini BB, Campanha RL, Nascimento M, Abreu Horta L, et al. Tratamento endovascular em paciente portador de coarctação da aorta: relato de caso. J Vasc Bras. 2007;6(1):82-5.

36. Suradi H, Hijazi ZM. Current management of coarctation of the aorta. Glob Cardiol Sci Pract. 2015;2015(4):44.

37. Bhatt AB, Foster E, Kuehl K, Alpert I, Brabeck S, Crumb S, et al. Congenital heart disease in the older adult: a scientific statement from the American Heart Association. Circulation. 2015;131(21):1884-931.

38. Tanous D, Benson LN, Horlick EM. Coarctation of the aorta: evaluation and management. Curr Opin Cardiol. 2009;24(6):509-15.

39. Amaral F, Granzotti JA, Nunes MA, Somerville J. Qualidade de vida após correção cirúrgica de coarctação da aorta: análise retrospectiva de um grupo de pacientes seguidos a longo prazo. Arq Bras Cardiol. 1997;68(6):421-7.

40. Pfeiffer MET. Coarctação da aorta, hipertensão arterial e exercício: considerações no seguimento de longo prazo. Rev DERC. 2011;17(2):50-3.

41. Vergales JE, Gangemi JJ, Rhueban KS, Lim DS. Coarctation of the aorta: the current state of surgical and transcatheter therapies. Curr Cardiol Rev. 2013;9(3):211-9.

42. Reddy VJR, Setty HSN, Reddy B, Ma njunath CN. Stenting of aortic coarctation: immediate and intermediate follow-up results. | Cardiovasc Disease Res. 2017;8(3):72-7. 